\title{
INTEGRASI DAKWAH DAN EKONOMI ISLAM
}

\author{
Husnul Hatimah dan Rahmad Kurniawan
}

\begin{abstract}
Abstrak
Tujuan dakwah adalah membuat perubahan dalam diri manusia, baik untuk membentuk sifat adil maupun aktual, baik individu maupun keluarga masyarakat, way of thinking atau cara berpikirnya berubah, way of life atau cara hidupnya berubah menjadi lebih baik ditinjau dari segi kualitas maupun kuantitas. Intinya dakwah bertujuan untuk mengubah sikap mental dan tingkah laku manusia yang kurang baik menjadi lebih baik atau meningkatkan kualitas iman dan Islam seseorang secara sadar dan timbul dari kemauannya sendiri tanpa merasa terpaksa siapapun. Selanjutnya dalam Ekonomi, Islam menempatkan bahwa tujuan ekonomi tidak hanya kesejahteraan duniawi saja, tapi juga untuk kepentingan yang lebih utama yaitu kesejahteraan ukhrawi.

Tujuan utama penulisan ini adalah untuk mengkaji masalah-masalah mendasar sebagai berikut: pertama bagaimana integrasi dakwah dan ekonomi Islam?, serta bagaimana dakwah Ekonomi Islam dalam membangun ekonomi umat? Dengan demikian tujuan penulisan ini adalah untuk mengkaji integrasi dakwah dan ekonomi Isam; untuk mengetahui dakwah ekonomi Islam dalam membangun ekonomi umat.

Tulisan ini termasuk kajian pustaka, sehingga metode pendekatan dilakukan berdasarkan pada kaidah-kaidah penelitian kepustakaan (library research). Penelitian kepustakaan yaitu penelitian yang dilakukan melalui bahan-bahan pustaka atau literatur kepustakaan sebagai sumber tertulis. Pendekatan tersebut adalah pendekatan kontekstual dan melalui pendekatan konseptual.

Hasil penelitian ini menyimpulkan bahwa integrasi dakwah dan ekonomi Islam bertujuan agar manusia memperoleh kebahagian dunia dan akhirat (Falah). Ekonomi Islam dan dakwah merupakan sarana untuk menyeru manusia agar dalam tindak tanduknya dalam kegiatan muamalah terutama dalam kegiatan perekonomian agar sesuai dengan nilai-nilai ajaran Islam. Selanjutnya dakwah ekonomi islam dalam membangun ekonomi umat dilaksanakan dengan cara mengubah pola pikir masyarakat yang berideologi konsumtif menjadi produktif agar bisa menggerakaan roda perekonomian. Pengembangan teknologi meyesuiakan dengan kebutuhan zaman penting dilakukan agar tidak tertinggal, serta pengembangan keterampilan agar mampu bersaing. Selanjutnya agar memanfaatkan dengan benar lembaga dakwah, sehingga lembaga tersebut benar-benar optimal dalam membangun ekonomi umat.
\end{abstract}

Kata Kunci: integrasi, dakwah, ekonomi islam

\section{PENDAHULUAN}

\section{Latar Belakang}

Keberadaan dakwah dalam Islam menduduki posisi yang sangat penting dan strategis. Dakwah berfungsi dan bertujuan sebagai upaya merekonstruksi masyarakat muslim sesuai dengan cita-cita sosial Islam melalui pelembagaan ajaran Islam sebagai rahmat bagi seluruh alam semesta (rahmatan lil 'alamin). Sosialisasi Islam melalui dakwah diharapkan akan memungkinkan proses islamisasi nilai-nilai sehingga dihayati dan diamalkan dalam kehidupan individu, keluarga, masyarakat dan negara untuk kebahagiaan manusia dunia dan akhirat. 
Pemahaman yang demikian menempatkan dakwah sebagai program besar dan penting atau azmil umur sebagaimana termaktub dalam Alquran Surah Lukman ayat 17:

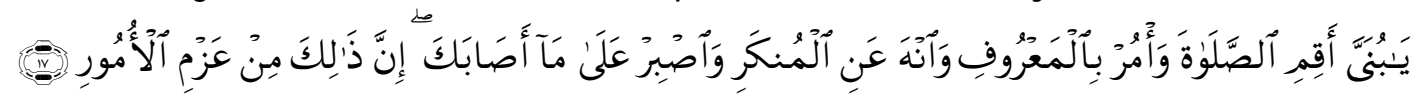

Artinya : Hai anakku, dirikanlah shalat dan suruhlah (manusia) mengerjakan yang baik dan cegahlah (mereka) dari perbuatan yang mungkar dan bersabarlah terhadap apa yang menimpa kamu. Sesungguhnya yang demikian itu Termasuk hal-hal yang diwajibkan (oleh Allah). ${ }^{1}$

Dari ayat tersebut tersirat bahwa aktivitas dakwah menuntut keterlibatan semua umat Islam dalam berbagai profesi dan keahlian, untuk selalu berbuat kebaikan dan mencegah kemungkaran. Hal ini menegaskan bahwa Agama Islam tidak hanya mengatur hubungan antara manusia dengan Tuhannya secara vertikal2 dalam konteks shalat dalam ayat tersebut (ibadah), tetapi secara horizontal juga mengatur hubungan antar sesama manusia termasuk dalam kegiatan muamalah. ${ }^{3}$ Muamalah adalah salah satu aspek dari ajaran yang telah melahirkan peradaban Islam yang maju di masa lalu hingga masa sekarang. Muamalah merupakan satu bagian dari syariat Islam, yaitu mengatur kehidupan manusia dengan manusia, masyarakat dan alam. Oleh karena itu muamalah juga mengandung aspek teologis dan spiritual.

Kegiatan transaksi dalam muamalah dinamakan kegiatan ekonomi. Oleh karena itu ekonomi sebagai satu aspek kehidupan, tentu juga sudah diatur oleh Islam. Ekonomi Islam merupakan konsekuensi logis dari kesempurnaan ajaran agama Islam. Ajaran Islam haruslah dijalankan secara kafah dan komprehensif oleh umatnya. Islam menuntut kepada umatnya untuk mewujudkan keislamannya dalam seluruh aspek kehidupan agar tidak menyimpang dari ajaran Islam, khususnya dalam muamalah, seperti jual beli, gadai, sewa-menyewa kerjasama dan interaksi muamalah lainnya yang sesuai dengan konsep ekonomi Islam yang sesuai ajaran Islam. 4

Berdasarkan tujuan ekonomi Islam yaitu mencapai falah, demi kesejahteraan umat Islam dan menghindari terjadinya penyimpangan dalam muamalah, Allah SWT telah menetapkan batas-batas tertentu terhadap perilaku manusia sehingga dapat memberikan keuntungan kepada satu individu tanpa mengorbankan hak-hak individu lainnya. ${ }^{5}$ Hal tersebut termuat dalam asas ekonomi Rabbani ${ }^{6}$ dan Insani ${ }^{7}$ yang semuanya itu juga bersumber dari Alquran dan hadis. ${ }^{8}$ Secara tegas ajaran Islam dalam muamalah mengatur kegiatan ekonomi berdasarkan ajaran Islam yang juga disebut ekonomi Islam.

Dari hal tersebut dapat dikonseptualkan bahwa tujuan dari ekonomi Islam dan dakwah bertujuan agar manusia memperoleh kebahagian dunia dan akhirat (Falah). Ekonomi Islam dan

1 Q.S. Lukman [31]:17.

2 Hubungan manusia dengan Tuhannya, dalam artian menyembah kepada sang pencipta.

3 Secara arti kata mengandung arti "saling berbuat" atau berbuat secara timbal balik. Lebih sederhana lagi berarti "hubungan antara orang dengan orang. Lihat Abdul Rahman Gazali, dkk, Fiqh Muamalat, Jakarta:Kencana, 2008, h. 3.

4 Mustafa Edwin Nasution, dkk, Pengenalan Eksklusif Ekonomi Islam,Jakarta: Kencana, 2007, h. 1-2.

5 Aturan-aturan itu sendiri berasal dari kerangka konseptual masyarakat dalam hubungannya dengan Kekuatan Tertinggi (Allah), kehidupan, sesama manusia, dunia, sesama makhluk dan tujuan akhir manusia. Segala aturan yang diturunkan Allah swt dalam sistem Islam adalah untuk mengarah pada tercapainya kebaikan, kesejahteraan, keutamaan, serta menghapuskan kejahatan, kesengsaraan, dan kerugian pada seluruh ciptaan-Nya. Demikian pula dalam hal ekonomi, tujuannya adalah membantu manusia mencapai kemenangan di dunia dan di akhirat. Lihat Mustafa Edwin Nasution, dkk, Pengenalan Eksklusif Ekonomi Islam .., 2007, h. 5.

6 Rabbani karena sarat dengan arahan dan nilai-nilai Ilahiyah.

7 Insani karena ekonomi ini dilaksanakan dan ditujukan untuk kemakmuran manusia.

8 Menurut Yusuf Qardhawi yang saya kutip dari buku terjemahannya ekonomi Islam memiliki tiga prinsip dasar yaitu tauhid, akhlak, dan keseimbangan. Dan juga sebagaimana dikatakan Syed Nawab Naqvi dalam bukunya Muhammad di dalam bukunya PrinsipPrinsip Ekonomi Islam dan Aspek Hukum Dalam Muamalat tentang prinsip-prinsip ekonomi Islam mencakup empat unsur yaitu: Tauhid, Keseimbangan, Kebebasan, tanggung jawab. Ini adalah sebagai landasan untuk membentuk etika dan moral atau bisa dikatakan character building pembentukan karakter. Lihat Yusuf Qardhawi, Peran Nilai dan Moral dalam Perekonomian Islam, Robbani Press: Jakarta, 2004, h. 56, dan Muhammad, Aspek Hukum Dalam Muamalat, Yogyakarta: Graha Ilmu, 2007, h. 80, dan Muhammad, Prinsip-Prinsip Ekonomi Islam, Yogyakarta: Graha Ilmu, 2007, h. 43. 
dakwah merupakan sarana untuk menyeru manusia agar dalam tindak tanduknya sesuai dengan nilai-nilai ajaran Islam.

\section{PEMBAHASAN}

\section{Terminologi Dakwah}

Secara etimologis, dakwah berasal dari bahasa arab, yaitu da'a, yad'u, da'wan, du'a. ${ }^{9}$ Dalam ilmu bahasa arab, kata dakwah berbentuk sebagai "isim mashdar" kata ini berasal dari fi'il (kata kerja) "da'a-yad'u" yang diartikan sebagai mengajak/ menyeru, memanggil, seruan, permohonan dan permintaan. ${ }^{10}$

Menurut pendapat ulama Bashrah, dasar pengambilan kata dakwah itu adalah dari kata mashdar yakni da'watan yang artinya panggilan. Sedangkan menurut ulama Kuffah perkataan dakwah itu diambil dari akar kata da'aa yang artinya telah memanggil.11

Adapun definisi Dakwah secara istilah menurut para ahli, antara lain:

1. Menurut Syekh Ali Mahfudz

"Dakwah adalah mendorong manusia kepada kebaikan dan petunjuk, memerintahkan perbuatan yang diketahui kebenarannya, melarang perbuatan yang merusak individu dan orang banyak agar mereka memperoleh kebahagiaan di dunia dan di akhirat". ${ }^{12}$

2. Menurut Muhammad Kidr Husain dalam bukunya Dakwah Ila Ishlah "Dakwah adalah upaya memotivasi seseorang agar berbuat baik dan mengikuti jalan petunjuk dan melakukan amar ma'ruf nahi munkar dengan tujuan mendapatkan kesuksesan dan kebahagiaan di dunia dan di akhirat". ${ }^{13}$

3. Menurut Muhammad Al Ghazali dalam bukunya Ma'allah:" Bahwa dakwah adalah program pelengkap yang meliputi semua pengetahuan yang dibutuhkan manusia untuk memberikan penjelasan tentang tujuan hidup."14

Dari beberapa pengertian tersebut, maka dapat diketahui bahwa dakwah adalah segala usaha yang bersifat menyeru, mengajak, memanggil, membimbing manusia baik secara perorangan, maupun kelompok dalam mengaktualisasaikan ajaran Islam dalam kehidupan seharihari, baik dalam kehidupan pribadi, keluarga maupun masyarakat sesuai dengan nilai-nilai Islam untuk tercapainya kebahagiaan dunia dan akhirat, dengan menggunakan berbagai media maupun cara yang sesuai dengan kaidah-kaidah agama dan kondisi mad'u atau sasaran dakwah. ${ }^{15}$

Tujuan dakwah secara umum menurut Munir adalah mengubah perilaku sasaran agar mau menerima ajaran Islam dan mengamalkannya dalam kehidupan sehari-hari, baik yang bersangkutan dengan masalah pribadi, keluarga maupun sosial kemasyarakatnya, agar mendapatkan keberkahan dari Allah Swt. Sedangkan tujuan dakwah secara khusus dakwah merupakan perumusan tujuan umum sebagai perincian daripada tujuan dakwah.16

\section{Ekonomi Islam}

Berbagai ahli ekonomi Muslim memberikan pengertian ekonomi Islam yang bervariasi, tetapi pada dasarnya mengandung makna yang sama. Pada intinya ekonomi Islam adalah suatu

\footnotetext{
${ }^{9}$ Muhammad Munir, Wahyu Ilahi, Manajemen Dakwah, Cet.I, Jakarta: Kencana, 2006, h.17.

${ }^{10}$ Syaiful Bahri Djamarah dan Aswan Zain, Strategi Belajar Mengajar, Jakarta: Rineka Cipta, 1996, h.17.

${ }^{11}$ Alwisral Imam Zaidillah, Strategi Dakwah dalam Membentuk Da'i dan Khatib Professional, Cet. I, Jakarta: Kalam Mulia, 2002 , h. 2.

${ }^{12}$ Siti Zainab, Harmonisasi dakwah dan Komunikasi, Cet.I, Banjarmasin: Antasari Press, 2009, h. 32.

13Moh. Ali Aziz, Ilmu Dakwah, Cet. I, Jakarta: Prenada Media, 2004, h.1.

14Ibid, h. 2.

15Ibid, h.3.

16Munir, Metode Dakwah, Cet.I, Jakarta: Kencana, 2003 h. 29.
} 
cabang ilmu pengetahuan yang berupaya untuk memandang, menganalisis, dan akhirnya menyelesaikan permasalahan-permasalahan ekonomi dengan cara-cara Islami.

Menurut pandangan Islam, ilmu pengetahuan adalah suatu cara yang sistematis untuk memecahkan masalah kehidupan manusia yang mendasarkan segala aspek tujuan (ontologis), metode penurunan kebenaran ilmiah (epistemologis), dan nilai-nilai (aksiologis) yang terkandung pada ajaran Islam. Secara singkat, ekonomi Islam dimaksudkan untuk mempelajari upaya manusia untuk mencapai falah dengan sumber daya yang ada melalui mekanisme pertukaran. Penurunan kebenaran atau hukum dalam ekonomi Islam didasarkan pada kebenaran deduktif wahyu Ilahi (ayat qauliyah) yang didukung oleh kebenaran induktif empriris (ayat kauniyah). Ekonomi Islam juga terikat oleh nilai-nilai yang diturunkan dari ajaran Islam itu sendiri. ${ }^{17}$

Definisi dari para ahli mengenai ekonomi Islam adalah sebagai berikut:

Pendekatan definisi oleh Hanazuzzaman dan Metwally yang dikutip oleh P3EI UII Yogyakartan:

Ekonomi Islam merupakan ilmu ekonomi yang diturunkan dari ajaran Alquran dan Hadis. Segala bentuk pemikiran ataupun praktek ekonomi yang tidak bersumberkan dari Al quran dan Hadis tidak dapat dipandang sebagai ekonomi Islam.Untuk dapat menjelaskan masalah kekinian digunakan metode fikih untuk menjelaskan fenomena tersebut sesuai dengan ajaran Alquran dan Hadis. ${ }^{18}$

Muhammad Abdul Mannan yang dikutip oleh Heri Sudarsono memberikan pengertian: Ekonomi Islam adalah merupakan ilmu pengetahuan sosial yang memperlajari masalah-masalah ekonomi rakyat yang diilhami oleh nilai-nilai Islam. ${ }^{19}$

Pendekatan yang digunakan Siddiqie dan Naqvi yang dikutip dari P3EI UII Yogyakarta, Ekonomi Islam merupakan representasi perilaku ekonomi umat Muslim untuk melaksanakan ajaran Islam secara menyeluruh. Dalam hal ini, ekonomi Islam tidak lain merupakan penafsiran dan praktek ekonomi yang dilakukan oleh umat Islam yang tidak bebas dari kesalahan dan kelemahan. Analisis ekonomi setidaknya dilakukan dalam tiga aspek, yaitu norma dan nilai-nilai dasar Islam, batasan ekonomi dan status hukum, dan aplikasi dan analisis sejarah.

Beberapa ekonom muslim mencoba mendefinisikan ekonomi lebih komprehensif ataupun menghubungkan antara definisi-definisi yang telah ada. Seperti yang diungkapkan Chapra dan Choudury bahwa berbagai pendekatan dapat digunakan untuk mewujudkan ekonomi Islam, baik pendekatan historis, empiris ataupun teroretis.Pendekatan ini dimaksudkan untuk mewujudkan kesejahteraan manusia sebagaimana yang dijelaskan oleh Islam, yaitu Falah, yang bermaknakan kelangsungan hidup, kemandirian, dan kekuatan untuk hidup.

Dapat disimpulkan dari beberapa paparan bahwa ekonomi Islam tidak hanya praktek kegiatan ekonomi yang dilakukan oleh individu dan komunitas Muslim yang ada, namun juga merupakan perwujudan perilaku ekonomi yang didasarkan pada ajaran Islam.Ia mencakup cara memandang permasalahan ekonomi, menganalis, dan mengajukan alternatif solusi berbagai permasalahan ekonomi. Ekonomi Islam merupakan konsekuensi logis dari implemantasi ajaran Islam secara kaffah dalam aspek ekonomi. Oleh karena itu, perekonomian Islam merupakan suatu tatanan perekonomian yang dibangun atas nilai-nilai ajaran Islam yang diharapkan, yang belum tentu tercermin dalam perilaku masyarakat muslim yang ada pada saat ini. ${ }^{20}$

Dapat penulis tarik benang merah ekonomi Islam adalah ilmu yang mempelajari usaha manusia untuk memenuhi kehidupannya untuk mengalokasikan dan mengelola sumber daya

\footnotetext{
17P3EI UII Yogyakarta, Ekonomi Islam, Jakarta: Rajawali Press, 2012, h. 17.

18Ibid.,h. 18

${ }^{19}$ Heri Sudarsono, Konsep Ekonomi Islam Suau Pengantar.., h. 13.

20P3EI UII Yogyakarta, Ekonomi Islam, Jakarta: Rajawali Press, 2012, h. 20.
} 
yang ada guna mencapai kebahagiaan dunia dan akherat yang berorienatasi mencapai falah berdasarkan prinsip-prinsip dan nilai-nilai Alquran dan Hadis.

\section{Tujuan Dakwah Ekonomi}

Tujuan dakwah dalam ekonomi secara sfesifik akan diuraikan sebagaimana berikut.

1. Mengutamakan Ketuhanan (Mencari kehidupan akhirat)

Maksud tujuan yang pertama kali dari ekonomi Islam ialah berbakti kepada Allah SWT. Tujuan ini untuk memperingatkan kepada masing-masing manusia bahwa dibalik hidupnya yang sekarang, masih ada lagi kehidupan yang abadi. Di sana hanyalah hukuman Tuhan yang berlaku, dimana tiap-tiap orang harus mempertanggung jawabkan segala perbuatan segala perbuatan selama hidup di dunia di hadapan Tuhan yang Maha Kuasa.

Dalam berjuang mencari rizki dan membangun perekonomian, haruslah orang mengingat tujuan akhir. Tujuan ini harus dijadikan lambang pekerjaannya dan juga dasar taktik strategi perjuangannya dilapangan ekonomi itu. Tujuan itu mempengaruhi pekerjaannya di lapangan produksi, distribusi, dan konsumsi.21

2. Memenuhi Kebutuhan Hidup Seseorang Secara Sederhana

Aspek yang tercakup dalam kategori ini termasuk usaha untuk mendapatkan makanan, minuman, pakaian, tempat perlindungan, perawatan, dan pendidikan. Sehubungan dengan tujuan yang benar, semua usaha yang dilakukan untuk mencapai tujuan ini adalah sunah, dan ia dianggap sebagai usaha yang diridhoi Allah. Dengan demikian, seseorang yang cukup pangan, mengenakan pakaian bagus, dan menikmati berbagai kesenangan lain dengan baik, merupakan tujuan yang hendak dicapai dalam Islam. ${ }^{22}$

3. Memperjuangkan Kebutuhan Hidup Duniawi (Dan janganlah melupakan nasibmu di dunia)

Di dalam tujuan yang ini Islam menegaskan bahwa ekonomi haruslah ditujukan kepada perjuangan nasib. Kita tidak boleh melalaikan nasib kita dalam hidup di dunia ini, melainkan harus hidup berjuang di lapangan perekonomian dengan segala jalan yang terbuka baginya. Banyak jalan yang bisa ditempuh dan banyak usaha yang dikerjakan untuk menolong nasib sendiri di dalam perebutan ekonomi. ${ }^{23}$

4. Memenuhi Kebutuhan Jangka Panjang

Islam juga mengakui tentang perlunya manusia menyimpan barang kebutuhan untuk digunakan pada saat tertentu. Sesuai dengan QS. Al-Isra' : 29:

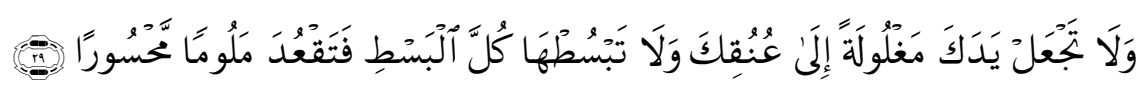

Artinya: "dan janganlah engkau membelenggu tanganmu di lehermu (terlalu kikir) dan jangan pula engkau terlal umemboroskannya, karena engkau akan mendapatkan celaan dan cemoohan. (QS. Al-Isra'[17]: 29)

Nabi Muhammad SAW sering memperingati sahabat-sahabatnya agar bersifat hemat dan menasehati agarjangan menghabiskan semua harta yang ada walaupun harta tersebut digunakan untuk jalan Allah, karena harta tersebut dibutuhkan untuk keperluan hidup sehari-hari dan untuk masa depan. ${ }^{24}$

5. Memberikan Bantuan Sosial dan Sumbangan Berdasarkan Jalan Allah

\footnotetext{
${ }^{21}$ M. Saefudin Ahmad, Ekonomi dan Masyarakat dalam Perspektif Islam, Jakarta: Rajawali, 2005, h. 170-175.

22Ibrahim Lubis, Ekonomi Islam, SuatuPengantar 1, Jakarta: Kalam Mulia, 2004, h. 158-166

${ }^{23}$ Aris, Dakwah di bidang Ekonomi, http:/ / arisemangatselalu.blogspot.co.id/ 2012/ 02/ dakwah-bidang-ekonomi.html

24Muhammad Nejatullah Siddiqi, KegiatanEkonomiDalam Islam, Jakarta :BumiAksara, 2002, h 16
} 
Permasalah dalam ekonomi kebanyakan membahsa masalah pendapatan dan pengeluaran, dan masalah ini merupakan aspek yang paling penting dalam aktifitas ekonomi manusia. Setelah seseorang dapat memuaskan kebutuhan hidupnya dan juga kebutuhan orang-orang berada dibawah pengawasannya, juga menyimpan beberapa bagian hartanya di masa yang akan datang dan keturunannya, seseorang tidak pantas untuk berdiam diri saja tanpa melakukan aktivitas ekonomi. Misalnya, memberikan bantuan sosial pada fakir miskin dan sumbangan sosial berdasarkan di jalan Allah dengan cara zakat, infaq, sedekah,dan lainnya.

\section{Integrasi Dakwah dan Ekonomi Islam}

Berdasarkan uraian yang sudah dibahas bahwa kegiatan perekonomian mempunyai tempat yang istimewa dalam Islam. Islam sebagai ajaran universal dengan jelas dan tegas tidak memisahkan masalah keduniaan dan keagamaan dengan ekonomi atau bisa disebut juga satu kesatuan yang saling terintegrasi.

Pengintegrasian dakwah dengan ekonomi Islam diharapkan agar terjadinya perubahan dalam kegiatan perkonomian dalam diri manusia, baik kelakuan adil maupun aktual, baik pribadi (character building) maupun keluarga masyarakat, way of thinking atau cara berpikirnya berubah, way of life atau cara hidupnya berubah menjadi lebih baik ditinjau dari segi kualitas maupun kuantitas. Yang dimaksud adalah nilai-nilai agama sedangkan kualitas adalah bahwa kebaikan yang bernilai agama itu semakin dimiliki banyak orang dalam segala situasi dan kondisi.

Ketika merumuskan pengertian dakwah, Amrullah Ahmad menyinggung tujuan dakwah adalah untuk mempengaruhi cara merasa, berpikir, bersikap, dan bertindak manusia pada dataran individual dan sosiokultural dalam rangka terwujudnya ajaran Islam dalam semua segi kehidupan. ${ }^{25}$

Tanpa adanya dakwah, maka masyarakat muslim tidak akan ada. Dengan demikian, dakwah merupakan pergerakan yang berfungsi mentransformasikan Islam sebagai ajaran (doktrin) menjadi kenyataan tata masyarakat dan peradabannya yang mendasarkan pada pandangan dunia Islam yang bersumber pada al-Qur'an dan al-Sunnah. Dakwah merupakan aktualisasi atau realisasi salah satu fungsi kodrati seorang muslim, yaitu fungsi kerisalahan berupa proses pengkondisian agar seseorang atau masyarakat mengetahui, memahami, mengimani dan mengamalkan Islam sebagai ajaran dan pandangan hidup (way of life). ${ }^{26}$

Kedua pendapat di atas menekankan bahwa dakwah bertujuan untuk mengubah sikap mental dan tingkah laku manusia yang kurang baik menjadi lebih baik atau meningkatkan kualitas iman dan Islam seseorang secara sadar dan timbul dari kemauannya sendiri tanpa merasa terpaksa oleh apa dan siapapun.

Salah satu tugas pokok dari Rasulullah adalah membawa mission sacre (amanah suci) dengan menanamkan akhlak yang mulia bagi manusia. Akhlak yang dimaksudkan tidak lain adalah Alquran itu sendiri. Atas dasar ini tujuan dakwah secara luas, dengan sendirinya adalah menegakkan ajaran Islam kepada setiap insan baik individu maupun masyarakat sehingga ajaran tersebut mampu mendorong suatu perbuatan sesuai dengan ajaran Islam. ${ }^{27}$

Sepanjang perjalanan dakwah NabiMuhammad SAW dalam menyiarkanagama Islam, penerapan nilai dan praktik ekonomi Islam juga menjadi perhatian besar bagi nabi mengingat di daerah Makkah merupakan daerah perdagangan terbesar saat itu. Hal ini untuk menghindari

\footnotetext{
${ }^{25}$ Amrullah Ahmad, Dakwah Islam dan Perubahan Sosial, Yogyakarta: Primaduta,2003, h. 2.

${ }_{26}$ M. Anis Bahtiar, Dakwah Kolaboratif: Model Alternatif Komunikasi Islam Kontemporer, Jurnal Komunikasi Islam | Volume 03,

Nomor 01, Juni 2013, h. 156.

27Toto Tasmara, Komunikasi Dakwah, Jakarta: Gaya Baru Pertama, 2003, h. 47.
} 
terjadinya berbagai macam kecurangan dalam transaksi perdagangan. Banyak Sunnah dan hadits nabi Muhammad SAW yang menjelaskan tentang petunjuk dalam bermuamalah (berdagang) dan mengelola negara ketika nabi menjadi khalifah. ${ }^{28}$

Sedangkan dalam konteksnya dengan ekonomi Islam, bahwa ekonomi Islam merupakan sekumpulan dasar-dasar umum ekonomi yang disimpulkan dari Alquran dan as-sunah dan merupakan bangunan perekonomian yang didirikan atas dasar-dasar tersebut sesuai dengan lingkungan dan masanya. ${ }^{29}$

Dalam berbagai pengertian ekonomi, baik yang dikemukakan oleh para pakar ekonomi Barat maupun oleh para pakar ekonomi Islam sendiri menempatkan individu (manusia) sebagai obyek kajian ekonomi. Namun demikian, konsep ekonomi Islam tidak hanya mengkaji individu sebagai makhluk sosial, sebagaimana yang menjadi kajian ekonomi Barat, tapi lebih dari itu. Konsep ekonomi Islam juga menempatkan individu sebagai mahluk yang mempunyai potensi religius. ${ }^{30}$

Oleh sebab itu, dalam pemenuhan kebutuhannya, atau aktifitas ekonomi lainnya, ekonomi Islam menempatkan nilai-nilai Islam sebagai dasar pijakannya. Berbeda dengan konsep ekonomi Barat yang menempatkan kepentingan individu sebagai landasannya. Nilai-nilai Islam tidak hanya berkaitan dengan proses ekonomi, tapi juga berkaitan dengan tujuan dari kegiatan ekonomi. Islam menempatkan bahwa tujuan ekonomi tidak hanya kesejahteraan duniawi saja, tapi juga untuk kepentingan yang lebih utama, yaitu kesejahteraan ukhrawi. Dengan demikian ekonomi Islam dan dakwah bertujuan agar manusia memperoleh kebahagian dunia dan akhirat (Falah). Ekonomi Islam dan dakwah merupakan sarana untuk menyeru manusia agar dalam tindak tanduknya sesuai dengan nilai-nilai ajaran Islam.

\section{Dakwah Ekonomi Islam dalam membangun Ekonomi Umat}

Keberhasilan perjuangan menegakkan agama Islam hanya dapat berhasil kalau diperjuangkan dengan metode yang pernah dipergunakan oleh Rasulullah saw. Metode Rasulullah saw merupakan gerakan dakwah atau kemanusiaan yang meliputi enam hal, antara lain adalah sebagai berikut.

1. Gerakan moral yang didasarkan pada aqidah Islam, sehingga terbentuk akhlak yang baik.

2. Gerakan intelektualitas dan ilmu pengetahuan.

3. Gerakan sosial yang harmonis, rukun, damai, dan aman.

4. Gerakan ekonomi bisnis, untuk membangun kehidupan ekonomi yang sejahtera dengan membangun etos kerja yang kuat.

5. Gerakan pembinaan bangsa; gerakan bela agama.

Dari beberapa gerakan-gerakan dakwah tersebut, tersirat bahwa sangat penting kiranya dakwah dan ekonomi haruslah terintegrasi dalam menjalankannya.

Terkait hal tersebut, salah satu cendekiawan muslim Imam Suprayogo berpendapat bahwa :

Saya kira banyak orang bersepakat, umpama antara gerakan ekonomi dan dakwah disatukan, maka hasilnya akan lebih baik. Orang yang didakwahi akan mendapat keuntungan ganda, yaitu pengetahuan agama sekaligus tercukupi kebutuhan ekonominya. Dakwah menjadi lebih rasional, mengajak orang mencukupi dua kebutuhannya sekaligus, yaitu kebutuhan jasmani dan rohani.

Namun yang terjadi, kedua hal tersebut masih berjalan sendiri-sendiri. Orang mengembangkan ekonomi, jarang dikaitkan dengan dakwah. Demikian pula sebaliknya, banyak pendakwah yang

\footnotetext{
${ }^{28}$ Sri Ana Farhanah, Peran Ekonomi Islam dalam Dakwah Nabi Muhammad SAW, Alhadharah Jurnal Ilmu Dakwah Vol.14 No.28, JuliDesember 2015, h. 9.

${ }^{29} \mathrm{Ahmad}$ Muhammad al-Assal, Fathi Ahmad Ab al-Karim, Sistem, Prinsip, dan Tujuan Ekonomi Islam, terj. Imam saefudin, Bandung: Pustaka Setia, 1999, h. 17.

30M. A. Mannan, Islamic Economic: Theory an Practice Cambridge: The Islamic Academy, Edisi Revisi, 2006, h. 20.
} 
tidak didukung oleh sumber-sumber ekonomi. Keduanya berjalan sendiri-sendiri, akhirnya dakwahnya tertinggal. Sedangkan kegiatan ekonominya juga berhenti sebatas pada kegiatan ekonomi, dalam arti tidak ada nuansa dakwahnya. Sejarah dakwah Islam hingga berhasil, adalah dilakukan oleh para pedagang. Melalui perdagangan itu, maka secara pelan tetapi tepat, Islam diperkenalkan. Para pedagang yang menguasai ekonomi memberikan pengaruh dan akhirnya diikuti oleh banyak orang. Dengan demikian, kegiatan ekonomi untuk kepentingan dakwah dan atau dakwah melalui kegiatan ekonomi. Hasilnya, sebagaimana yang ditunjukkan dalam sejarah, terjadi penyebaran agama yang luar biasa cepat dan efektif. Dakwah dalam bentuknya kemudian adalah berupa organisasi sosial keagamaan yang tidak sedikit jumlahnya. Organisas tersebut disusun secara rapi, tetapi pada umumnya tidak didukung oleh dana yang memadai. Sebagai akibatnya, organisasi yang rapi itu banyak yang tidak berjalan. Organisasi dan orang-orang sebagai pengurusnya ada, tetapi kegiatannya yang kurang tampak. Sehingga, kalau boleh dikatakan, adanya sama dengan tidak adanya. Kita lihat saja banyak organisasi sosial keagamaan, tatkala muktamar selalu ramai dikunjungi oleh para pendukungnya. Jabatan dalam kepengurusan tidak jarang juga diperebutkan lewat pemilihan di antara mereka yang berhak dipilih dan memilih. Kadang terjadi saling mempengaruhi untuk memenangkan kandidatnya masing-masing. Tetapi apapun akhirnya, pimpinan dan segala kelengkapan organisasi terbentuk. Kepengurusan baru dan program kerja dihasilkan. Namun kadang, semangat organisasi itu tidak selalu bertahan lama. Rapat pengurus saja tidak mudah dilakukan, karena masing-masing sibuk dengan urusannya sendiri-sendiri. Umumnya organisasi memiliki kantor, tetapi sebatas siapa yang harus menjaga kantornya itu saja juga tidak mudah dilakukan. Belum lagi persoalan pendanaan, yang kadang juga tidak gampang didapat. Padahal untuk menggerakkan organisasi tidak akan mungkin dilakukan tanpa dana yang cukup. Akibatnya, organisasi tidak berjalan, bahkan sampai masa muktamar selanjutnya. Keadaan organisasi sosial keagamaan seperti itu menjadi lebih parah lagi tatkala budaya transaksional sudah semakin kuat di tengah-tengah masyarakat. Orang mau mengeluarkan uangnya manakala ada sesuatu yang diharapkan bisa diperoleh. Sebagai akibat budaya transaksional itu maka kebiasaan memberi, beramal, atau berkorban semakin menipis. Suasana seperti itu, menjadikan organisasi sosial keagamaan yang semestinya adalah merupakan kumpulan orang-orang yang mau memberikan pikiran, tenaga dan bahkan juga hartanya, tidak berjalan. Organisasihanya ramai tatkala menjelang dan sedang muktamar. Namun setelah itu, akan sepi kembali. Memperhatikan keadaan beberapa organisasi sosial keagamaan seperti itu, saya menjadi teringat pasar modern seperti Carrefour, indomart, alfamart dan sejenisnya. Pusat perbelanjaan modern itu sudah tersebar di mana-mana, bahkan hingga ke gang kecil sekalipun. Pusat perbelanjaan itu jika diupamakan sebagai organisasi, maka sudah menyerupai cabang dan ranting-ranting hingga unit yang paling kecil. Bedanya, di antara keduanya terletak pada tingkat profesionalitasnya. Organisasi bisnis ditata secara rapi dan professional. Sedang organisasi sosial keagamaan, pembawa misi dakwah, biasanya kurang memperhatikan prinsip-prinsip tersebut, sekalipun dikenal konsep amal shaleh, yang artinya adalah juga bekerja secara professional. Umpama organisasi dakwah dibarengi dengan usaha bisnis modern, seperti Carrefour, alfamart, dan indomart dan sejenisnya, maka akan lebih menarik dan berjalan. Dakwah akan terjadi sebagaimana sejarahnya dulu, yaitu melalui perdagangan. Sayangnya, pada perkembangan kemudian, pola itu tidak ditemukan lagi. Dakwah ya dakwah, bisnis ya bisnis. Justru di zaman modern seperti sekarang ini keduanya tidak mudah disatukan. Akhirnya dakwah tidak berjalan, dan demikian pula kegiatan bisnis tidak ada nuansa dakwahnya. Umpama keduanya itu berhasil disatukan, maka secara teoritik akan sangat menguntungkan. Sejarah dakwah yang gemilang akan terulang kembali. Namun memang pada kenyataannya, teori yang baik belum tentu berhasil dirupakan dalam kenyataan secara baik pula. Bahkan, organisasi yang maju, banyak dana yang terkumpul, maka juga segera muncul penyakit, yaitu konflik atau bertengkar dan akhirnya mati bersama-sama. Itulah penyakit ummat.31

Dari pendapat beliau tersebut penting kiranya agar antara gerakan ekonomi dan dakwah disatukan, maka hasilnya akan lebih baik. Orang yang didakwahi akan mendapat keuntungan ganda, yaitu pengetahuan agama sekaligus tercukupi kebutuhan ekonominya. Dakwah menjadi lebih rasional, mengajak orang mencukupi dua kebutuhannya sekaligus, yaitu kebutuhan jasmani dan rohani. Terintegrasinya gerakan ekonomi dan dakwah, kegiatan ekonomi untuk kepentingan dakwah dan atau dakwah melalui kegiatan ekonomi.

\footnotetext{
31Imam Suprayogo, Ekonomi dan Dakwah,
} 
Selanjutnya dari hal tersebut dikaitkan dengan konteks dalam membangun penguatan ekonomi umat, integrasi dakwah dan ekonomi harus membuat terobosan agar berupaya untuk pengembangan sumber daya manusia. Ada beberapa hal yang dilakukan dalam dakwah guna membangun ekonomi, antara lain seperti berikut.

Pertama, mengubah ideologi konsumtif menjadi ideologi produktif, penuh semangat dan berpola pada kemandirian. Upaya penegakkan masyarakat untuk orang kecil dilaksanakan dengan watak dari spiritualitas dan produktifitas yang tinggi. Pengaruh dakwah dalam menerapkan konsep ini bisa menumbuhkan kemampuan mandiri untuk meyakinkan bahwa sebenarnya manusia memiliki kemampuan untuk lepas dari kemiskinan, karena metode dakwah lebih fleksibel yang bergerak dari sisi spiritualitas dan doktrin agama.

Kedua, mengembangkan teknologi dan pemanfaatannya termasuk pengembangan keterampilan dan pengetahuan. Upaya ini bisa dilakukan dengan cara partisipatif dengan melibatkan mereka secara penuh, sejak dari proses perencanaan sampai evaluasi.

Ketiga, memanfaatkan dengan benar lembaga dakwah, sehingga lembaga tersebut benarbenar optimal. Firman Allah dalam QS ar-Ra'ad (13) : 11;

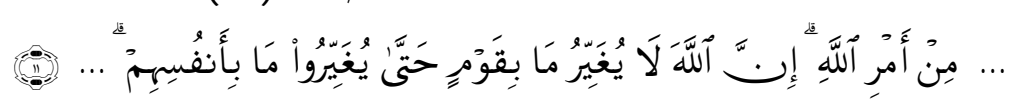

Artinya: ... Sesungguhnya Allah tidak merubah keadaan sesuatu kaum sehingga mereka merubah keadaan yang ada pada diri mereka sendiri ...

Hal ini juga senada dengan pendapat Imam Suprayogo bahwa "Dakwah dalam bentuknya kemudian adalah berupa organisasi sosial keagamaan yang tidak sedikit jumlahnya". Sehingga harus bisa dikelola dengan baik dan benar dalam rangka membangun ekonomi umat.

Dalam upaya pelaksanaan dakwah ini, mulai dari tantangan moral sampai tantangan politik. Bangsa Indonesia saat ini sudah terpuruk dalam krisis multidimensional; krisis kepercayaan (amanah), krisis moral, ekonomi, social politik, dan budaya. Oleh karena itu, untuk membangun aktifitas dakwah yang sanggup menghadapi tantangan merupakan suatu keharusan yang tidak boleh ditunda-tunda. Pada hakikatnya, dalam kegiatan ekonomi, motivasi merupakan proses pemenuhan kebutuhan. Kebutuhan merupakan keadaan internal yang membuat hasilhasil tertentu kelihatan menarik. Kebutuhan yang belum terpenuhi menciptakan ketegangan yang menimbulkan dorongan dalam diri individu.

Dorongan tersebut mengakibatkan perilaku mencari untuk mendapatkan tujuan tertentu, yang jika dicapai akan memuaskan kebutuhan dan menyebabkan pengurangan ketegangan. Untuk dapat merumuskan metode dan substansi dakwah yang tepat, maka kita harus mengenal siapakah manusia itu sebenarnya. Manusia dapat digambarkan sebagai mahluk yang berfikir, merasa dan bertindak. Peranan manusia dalam kehidupan di dunia ini ditandai oleh tindakan atau perilakunya. Dalam pemenuhan kebutuhan, motivasi manusialah yang merupakan latar belakang yang melandasi pemikiran manusia. Pengetahuan mengenai motivasi manusia memberikan jawaban terhadap pertanyaan mengapa seseorang melakukan suatu tindakan tertentu.

Manusia adalah mahluk yang mempunyai kebutuhan banyak sekali. Kebutuhan-kebutuhan ini menimbulkan banyak motif yang melatar belakangi kegiatan manusia. Walaupun begitu pada suatu saat tertentu manusia hanya melakukan kegiatan tertentu pula. Dalam konteks dakwah, perlu dipelajari motif manusia yang melakukan berbagai kejahatan. Dosa dan dusta serta penyimpangan dari norma-norma agama dan budaya. Hal ini sangat penting agar strategi dakwah yang dikembangkan mencapai sasaran yang diharapkan, sehingga dalam memenuhi kebutuhan hidupnya sesuai dengan ketentuan syari'. Dakwah sangat penting disampaikan kepada sese- 
orang yang memiliki perilaku negative, terutama dalam kegiatan perekonomian dalam rangka memenuhi kebutuhan hidupnya, baik itu kebutuhan jasmani maupun rohaninya. ${ }^{32}$

Dengan demikian, dapat menarik kesimpulan bahwa dakwah dan ekonomi Islam dalam membangun ekonomi umat tentunya sangat penting dilaksanakan dengan cara mengubah pola pikir masyarakat yang berideologi konsumtif menjadi produktif agar bisa menggerakaan roda perekonomian. Pengembangan teknologi meyesuaikan dengan kebutuhan zaman penting dilakukan agar tidak tertinggal, serta pengembangan keterampilan agar mampu bersaing. Selanjutnya agar memanfaatkan dengan benar lembaga dakwah, sehingga lembaga tersebut benar-benar optimal dalam membangun ekonomi umat.

\section{PENUTUP}

Integrasi dakwah dan ekonomi Islam bertujuan agar manusia memperoleh kebahagian dunia dan akhirat (Falah). Ekonomi Islam dan dakwah merupakan sarana untuk menyeru manusia agar dalam tindak tanduknya dalam kegiatan muamalah terutama dalam kegiatan perekonomian agar sesuai dengan nilai-nilai ajaran Islam. Integrasi ini diharapkan agar terjadinya perubahan dalam kegiatan perkonomian dalam diri manusia, baik kelakuan adil maupun aktual, baik pribadi (character building) maupun keluarga masyarakat, way of thinking atau cara berpikirnya berubah, way of life atau cara hidupnya berubah menjadi lebih baik ditinjau dari segi kualitas maupun kuantitas.

Dakwah ekonomi Islam dalam membangun ekonomi umat dilaksanakan dengan cara mengubah pola pikir masyarakat yang berideologi konsumtif menjadi produktif agar bisa menggerakaan roda perekonomian. Pengembangan teknologi menyesuaikan dengan kebutuhan zaman penting dilakukan agar tidak tertinggal, serta pengembangan keterampilan agar mampu bersaing. Selanjutnya agar memanfaatkan dengan benar lembaga dakwah sehingga lembaga tersebut benar-benar optimal dalam membangun ekonomi umat.

\section{DAFTAR PUSTAKA}

Ahmad, Amrullah. 2003. Dakwah Islam dan Perubahan Sosial. Yogyakarta: Primaduta.

Ahmad, M. Saefudin. 2005. Ekonomi dan Masyarakat dalam Perspektif Islam. Jakarta: Rajawali.

al-Assal, Ahmad Muhammad, Fathi Ahmad Ab al-Karim.1999. Sistem, Prinsip, dan Tujuan Ekonomi Islam. terj. Imam saefudin. Bandung: Pustaka Setia.

Aris, Dakwah di bidang Ekonomi, http:/ / arisemangatselalu.blogspot.co.id/ 2012/ 02/ dakwahbidang-ekonomi.html.

Aziz, Moh. Ali. 2004. Ilmu Dakwah, Cet. I, Jakarta: Prenada Media.

Bahtiar, M. Anis. Dakwah Kolaboratif: Model Alternatif Komunikasi Islam Kontemporer. Jurnal Komunikasi Islam | Volume 03, Nomor 01,Juni 2013.

Djamarah, Syaiful Bahri, Aswan Zain. 1996. Strategi Belajar Mengajar. Jakarta: Rineka Cipta.

Farhanah, Sri Ana. Peran Ekonomi Islam dalam Dakwah Nabi Muhammad SAW. Alhadharah Jurnal Ilmu Dakwah Vol.14 No.28, Juli-Desember 2015.

32Wordpress, Pengaruh Dakwah dalam Membangun Ekonomi Umat, Https://lengkas.wordpress.com/2012/ 04/ 03/ pengaruhdakwah-dalam-membangun-ekonomi-umat/, online 24 Oktober 2017. 
Gazali, Abdul Rahman, dkk. 2008. Fiqh Muamalat, Jakarta: Kencana.

Lubis, Ibrahim. 2204. Ekonomi Islam, SuatuPengantar 1.Jakarta: Kalam Mulia.

M. A. Mannan. 2006. Islamic Economic: Theory an Practice. Cambridge: The Islamic Academy.

Muhammad. 2007. Aspek Hukum Dalam Muamalat. Yogyakarta: Graha Ilmu.

Muhammad, Munir, Wahyu Ilahi. 2006. Manajemen Dakwah. Jakarta: Kencana.

Muhammad. 2007. Prinsip-Prinsip Ekonomi Islam. Yogyakarta: Graha Ilmu.

Munir. 2003. Metode Dakwah. Jakarta: Kencana.

Nasution, Mustafa Edwin, dkk. 2007. Pengenalan Eksklusif Ekonomi Islam. Jakarta: Kencana.

P3EI UII Yogyakarta. 2012 Ekonomi Islam. Jakarta: Rajawali Press.

Qardhawi, Yusuf. 2004. Peran Nilai dan Moral dalam Perekonomian Islam. Jakarta: Robbani Press.

Siddiqi, Muhammad Nejatullah. 2002. KegiatanEkonomi Dalam Islam. Jakarta: BumiAksara.

Tasmara, Toto. 2003. Komunikasi Dakwah. Jakarta: Gaya Baru Pertama.

Zaidillah, Alwisral Imam. 2002. Strategi Dakwah dalam Membentuk Da'i dan Khatib Professional. Jakarta: Kalam Mulia.

Zainab, Siti. 2009. Harmonisasi dakwah dan Komunikasi. Banjarmasin: Antasari Press.

Wordpress. Pengaruh Dakwah dalam Membangun Ekonomi Umat, Https:/ lengkas.wordpress.com/ 2012/ 04/ 03/ pengaruh-dakwah-dalam-membangun-ekonomi-umat/ online 24 Oktober 2017. 